\title{
Serum Insulin and Lipogenesis in the Suckling 'Fatty' fa/fa Rat
}

\author{
D. A. York, N. S. Shargill and V. Godbole \\ Department of Nutrition, School of Biochemical and Physiological Sciences, University of Southampton, UK
}

Summary. Preobese 'fatty' $f a / f a$ rats identified by their decreased rectal temperature were either given access to high carbohydrate chow or maintained on a suckling only diet till 20 days of age. Serum insulin, hepatic and adipose tissue fatty acid synthesis and lipogenic enzyme activities were low in suckling preobese $f a / f a$. In animals with access to chow diet, hepatic lipogenesis was unaltered, serum insulin rose to similar levels in lean and preobese $f a / f a$ (lean $62 \pm 5 ;$ preobese $69 \pm 4 \mu \mathrm{U} / \mathrm{ml}$ ), but adipose tissue lipogenesis was increased to higher levels in the preobese than lean rats (lean $0.56 \pm 0.12$; preobese $1.80 \pm 0.22 \mu \mathrm{mol}$. tissue $\left.{ }^{-1} \cdot \mathrm{h}^{-1}\right)$. The activities of glucose-6-phosphate dehydrogenase, acetyl coenzyme A carboxylase and fatty acid synthetase were increased in adipose tissue of preobese fa/fa rats. Neither streptozotocin treatment nor pretreatment with Triton WR 1339 abolished the difference in adipose tissue lipogenesis between lean and preobese $\mathrm{fa} / \mathrm{fa}$ rats. Preobese $f a / f a$ rats showed an enhanced insulin secretory response to a glucose load.

Key words: Preobesity, adipose tissue, lipogenesis, suckling, serum insulin, fatty rats, Triton WR 1339

The genetically obese fatty $(f a / f a)$ rat inherits the obesity as an homozygous recessive trait. It is characterised by a rapid increase in hepatic and adipose tissue lipogenesis after weaning which has been attributed mainly to their hyperinsulinaemia and hyperphagia [1-6]. In a previous paper, it was shown that serum insulin and hepatic fatty acid synthesis were normal in suckling preobese $f a / f a$ rats but that weaning was the signal for a massive increase in both parameters [2]. In contrast the hypothermia characteristic of adult $f a / f a$ rats was observed before weaning at 16 days of age suggesting that the primary genetic defect may be related to a thermogenic process. Body fat content is increased by 7-12 days of age and is accompanied by an increase in adipose tissue lipoprotein lipase activity [7-9]. As estimates of maternal milk intake have suggested that food intake of the preobese $f a / f a$ pups is normal, the early increase in body fat may be a result of the fall in energy expenditure on thermogenesis in the presence of normal food intake [7]. Similar observations have been reported for the obese $(o b / o b)$ and misty diabetic $(m d b / m d b)$ mice [for review: 10,11] which suggest that these metabolic abnormalities are characteristic of the recessively inherited obesities in rodents. While it has been suggested that serum insulin levels are normal in the suckling $f a / f a$ rat [2], an increase in insulin secretion has been reported before weaning in both misty diabetic $(m d b / m d b)$ [12] and obese $(o b / o b)$ mice [13]. It has been suggested from such data that the hypersecretion of insulin may be a fundamental defect in the genetic obesities but that this pancreatic defect is generally masked during the suckling period when the diet is effectively a high fat diet [10]. As suckling animals will begin to eat solid food before weaning when it is available, we have investigated the effect of the availability of high carbohydrate rat chow diet during the suckling period on serum insulin levels and upon the rates of hepatic and adipose tissue lipogenesis.

\section{Materials and Methods}

\section{Animals}

The lean $(f a / f a$ or $f a / f a)$ and obese $(f a / f a)$ rats used in these experiments were bred from lean heterozygote parents in the departmental animal facility. The animals were housed at $22^{\circ} \mathrm{C}$ under a 
controlled light-dark cycle $(06.00-20.00 \mathrm{~h})$. The suckling animals remained with the mother until the time of experimentation. In some litters, the pelleted maternal high carbohydrate rat chow diet ( $70 \%$ carbohydrate, $20 \%$ protein, $3 \%$ fat by weight) (Christopher Hill, Poole, Dorset) was freely available to the young pups, whereas other litters were housed in plastic cages with wire mesh bases in which the chow diet was too high to be reached by the pups and in which any spilled food fell through the wire mesh base, i. e. there was no access to solid food before weaning.

\section{Identification of Preobese fa/fa Rats}

Preobese falfa rats were identified on days $16-18$ by their decrease in rectal temperature [2]. A number of litters were treated with streptozotocin (a gift from Upjohn). Pups were injected IP between days $18-21$ with a freshly prepared solution of streptozotocin $(6.5 \mathrm{mg} / \mathrm{kg}$ body weight $)$ in citrate buffer $(0.05 \mathrm{~mol} / 1)$ $\mathrm{pH} 4.3$. Mortality varied from zero to $20 \%$ at this dose but increased dramatically at higher doses. The animals were used for experimental purposes three days after streptozotocin treatment (days 21-24) which necessitated delaying the normal weaning at day 21 in three litters.

Pups were taken from their mothers at $10.00 \mathrm{~h}$ for measurement of lipogenesis or lipogenic enzyme activities. All animals were sacrificed by decapitation.

\section{Lipogenesis}

Hepatic and adipose tissue lipogenesis was estimated from the incorporation of $\left[{ }^{3} \mathrm{H}\right]$ from ${ }^{3} \mathrm{H}_{2} \mathrm{O}$ by the method previously described [1], after injection of $4 \mathrm{mCi}^{3} \mathrm{H}_{2} \mathrm{O}$ (Radiochemical Centre, Amersham) IP into conscious rats at $10.00 \mathrm{~h}$. Animals were killed $1 \mathrm{~h}$ later and the incorporation of $\left[{ }^{3} \mathrm{H}\right]$ into fatty acids assessed.

The accumulation of $\left[{ }^{3} \mathrm{H}\right]$ in fatty acids was investigated in animals in which lipoprotein lipase was inhibited by Triton WR 1339. In these experiments rats were given $0.1 \mathrm{ml} 20 \%(\mathrm{w} / \mathrm{v})$ Triton WR 1339 (Sigma Chemical) in $0.9 \%$ ( $w / v)$ saline by intracardiac injection while under light ether anaesthesia. Four $\mathrm{mCi}$ ${ }^{3} \mathrm{H}_{2} \mathrm{O}$ was either included in the cardiac injection or given immediately by IP injection.

\section{Enzyme Activities}

Glucose-6-phosphate dehydrogenase (E.C.1.1.1.49) (G6PDH) was assayed on the $100,000 \mathrm{~g}$ supernatant of a $10 \%(\mathrm{w} / \mathrm{v})$ homogenate of liver or a $20 \%(\mathrm{w} / \mathrm{v})$ homogenate of adipose tissue in $50 \mathrm{mmol} / 1 \mathrm{Tris}, 5 \mathrm{mmol} / 1 \mathrm{MgSO}_{4}, 1 \mathrm{mmol} / \mathrm{L}$ EDTA, $\mathrm{pH} 7.6$ as previously described [2].

Acetyl CoA carboxylase (E.C.6.4.1.2) was assayed on the $45,000 \mathrm{~g}$ supernatant of a $10 \%(\mathrm{w} / \mathrm{v})$ homogenate of liver or adipose tissue in $100 \mathrm{mmol} / \mathrm{l}$ phosphate buffer, $\mathrm{pH} 7.5$, containing $2 \mathrm{mmol} / 1 \mathrm{EDTA}$ and $5 \mathrm{mmol} / \mathrm{l}$ glutathione by a method based upon that of Inoue and Lowenstein [14]. The enzyme was activated by incubation with $20 \mathrm{mmol} / 1$ citrate, $20 \mathrm{mmol} / 1 \mathrm{MgCl}_{2}$ and $1 \mathrm{~g} / 100 \mathrm{ml}$ delipidated albumin (Pentex Laboratories, London) at $37^{\circ} \mathrm{C}$ for $30 \mathrm{~min}$. An aliquot of the $45,000 \mathrm{~g}$ supernatant or of the activated supernatant was assayed for acetyl CoA carboxylase activity by following incorporation of $\mathrm{NaH}^{14} \mathrm{CO}_{3}$ (Radiochemical Centre, Amersham) into ${ }^{14} \mathrm{C}$-malonyl $\mathrm{CoA}$. The assay system contained $5 \mathrm{mmol} / 1 \mathrm{ATP}, 10 \mathrm{mmol} / 1 \mathrm{MgCl}_{2}, 0.5 \mathrm{mmol} / 1 \mathrm{EDTA}$, $1 \mathrm{mmol} / \mathrm{l}$ glutathione, $10 \mathrm{mg} / \mathrm{ml}$ delipidated bovine serum albumin fraction $\mathrm{V}, 15 \mathrm{mmol} / 1 \mathrm{KH}^{14} \mathrm{CO}_{3}$ (specific activity, $1 \mu \mathrm{Ci} / \mu \mathrm{mol}$ ), $0.15 \mathrm{mmol} / 1$ acetyl $\mathrm{CoA}$ in $0.1 \mathrm{~mol} / 1$ Tris buffer $\mathrm{pH} 7.4$. Incubations were for $3 \mathrm{~min}$ at $37^{\circ} \mathrm{C}$ and were terminated by addition of $10 \%(\mathrm{v} / \mathrm{v})$ perchloric acid.
Acetyl CoA was prepared by the addition of $100 \mu \mathrm{mol} \mathrm{KHCO}_{3}$ and $100 \mu \mathrm{mol}$ acetic anhydride to $10 \mathrm{mg}$ coenzyme A (Sigma Chemicals) in a final volume of $1 \mathrm{ml}$. $\mathrm{pH}$ was adjusted to 1.5 and the aqueous phase was extracted five times with $1 \mathrm{ml}$ ether. After adjustment of $\mathrm{pH}$ to 5.5 with $1 \mathrm{~mol} / 1 \mathrm{KHCO}_{3}$, nitrogen was bubbled through the solution to remove all traces of ether. The acetyl $\mathrm{CoA}$ solution was stored at $-10^{\circ} \mathrm{C}$.

Fatty acid synthetase activity was assayed on the $100,000 \mathrm{~g}$ supernatant of an homogenate of liver $(10 \% ; \mathrm{w} / \mathrm{v})$ or adipose tissue $(20 \% ; \mathrm{w} / \mathrm{v})$ in phosphate buffer $(100 \mathrm{mmol} / \mathrm{l})$ containing $70 \mathrm{mmol} / 1 \mathrm{KHCO}_{3}$ and $1 \mathrm{mmol} / 1$ dithiothreitol, $\mathrm{pH} 8.0$ by the method of Nepokroeff et al. [15]. Serum triacylglycerol was measured by an autoanalytical method [16].

\section{Serum Insulin}

Duplicate $100 \mu \mathrm{l}$ samples were used in a radioimmunoassay procedure using a human insulin standard in an immunoassay kit purchased from the Radiochemical Centre, Amersham [1].

In the experiment to investigate insulin secretion in response to a glucose load, serum insulin was assayed with a rat radioimmunoassay system (Novo Laboratories, Denmark). This system uses a rat insulin standard and ${ }^{125} \mathrm{I}$-porcine insulin label. Rat pups were separated from their mothers at $08.30 \mathrm{~h}$. Two hours later they were sacrificed or injected IP with glucose $(1 \mathrm{mg} / \mathrm{g}$ body weight) in aqueous solution. Pups were killed 15 and $30 \mathrm{~min}$ after glucose injection for collection of blood.

\section{Statistical Analysis}

Results are expressed as mean \pm SEM. The significance of any differences was assessed by Student's ' $t$ ' test.

\section{Results}

Positive identification of lean and preobese $f a / f a$ rats was made at days $16-18$ by their low rectal temperature [2] (Table 1). The serum insulin levels of the preobese $f a / f a$ rats used in this study were similar to those of lean pups at 20 days of age maintained on a suckling only diet. In those litters which were allowed access to the high carbohydrate chow, serum insulin was significantly elevated but lean and preobese $f a / f a$ rats continued to show similar values. Although there were only a relatively small number of preobese rats used in this study, analysis of a large number of serum insulin values from preobese rats used in other studies again fails to show any differences between lean and preobese rats with access to solid food (lean, $59 \pm 6$; preobese, $64 \pm 7 \mu \mathrm{U} / \mathrm{ml}$ for 108 and 45 animals respectively). Streptozotocin treatment significantly reduced serum insulin in both groups but this experimental procedure failed to lower the levels to those observed in litters denied access to chow diet.

Fatty acid synthesis was similar in both the liver and adipose tissue of lean and preobese $f a / f a$ pups with no access to solid food. When given access to rat chow, lipogenesis was enhanced in both the liver and 
Table 1. Fatty acid synthesis, rectal temperature and serum insulin in lean and preobese $f a / f a$ rats at 20 days of age: the effect of food availability and of streptozotocin

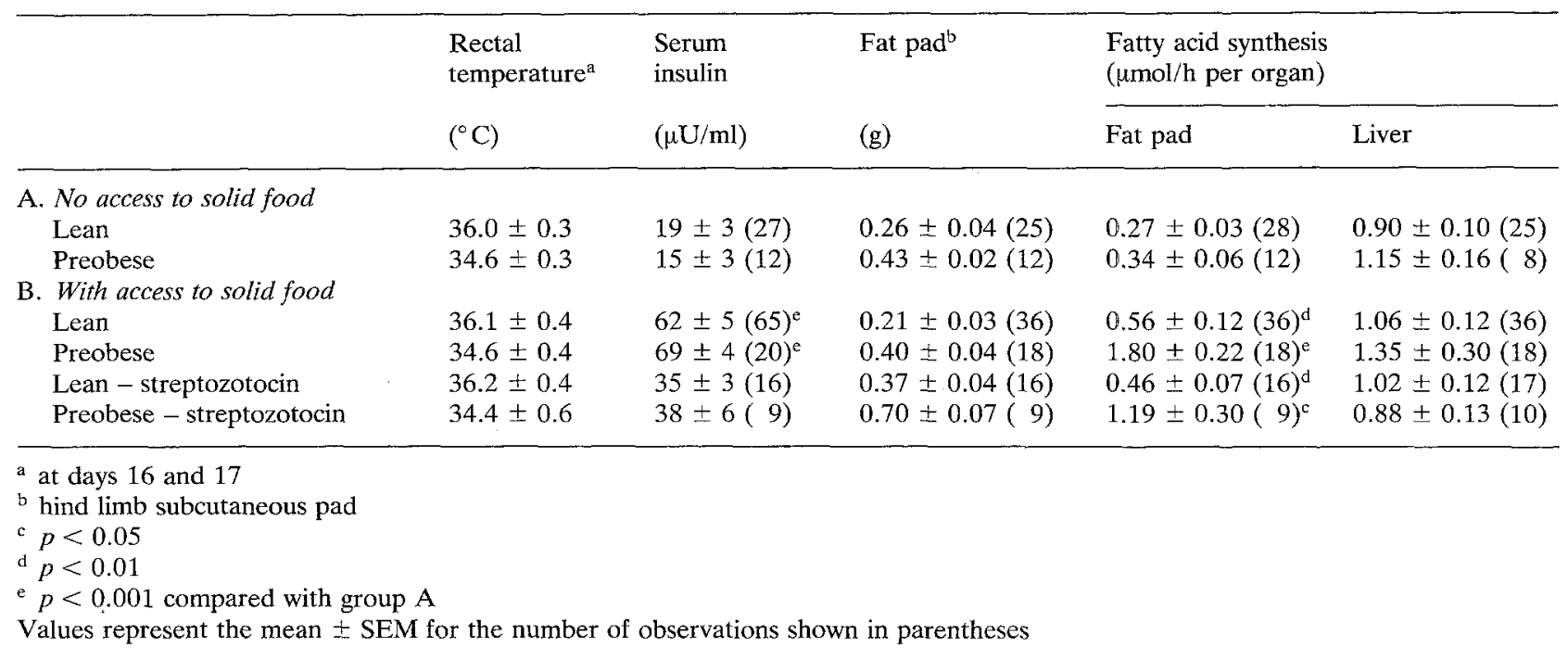

Table 2. The effect of availability of solid food on enzyme activities in adipose tissue and liver of lean and preobese $f a / f a$ rats

\begin{tabular}{|c|c|c|c|c|c|c|}
\hline & \multicolumn{6}{|c|}{ Enzyme activity (nmol/min per organ) } \\
\hline & \multicolumn{2}{|c|}{ Glucose-6-phosphate dehydrogenase } & \multicolumn{2}{|c|}{ Fatty acid synthetase } & \multicolumn{2}{|c|}{ Acetyl CoA carboxylase ${ }^{a}$} \\
\hline & Liver & Fat pad & Liver & Fat pad & Liver & Fat pad \\
\hline \multicolumn{7}{|c|}{ A. No access to solid food } \\
\hline Lean & $878 \pm 95(17)$ & $57 \pm 5(17)$ & $1193 \pm 172(17)$ & $10 \pm 1(15)$ & & \\
\hline Preobese & $1002 \pm 136(13)$ & $73 \pm 9(13)$ & $1519 \pm 287(13)$ & $9 \pm 2(13)$ & & \\
\hline \multicolumn{7}{|c|}{ B. With access to solid food } \\
\hline Lean & $1008 \pm 68(29)$ & $54 \pm 7(15)$ & $1369 \pm 213(29)$ & $10 \pm 1(15)$ & $400 \pm 100(25)$ & $2.4 \pm 0.9(25)$ \\
\hline Preobese & $1217 \pm 85(13)$ & $117 \pm 18(9)^{\mathrm{b}}$ & $1205 \pm 348(13)$ & $16 \pm 3(9)^{b}$ & $407 \pm 94(8)$ & $20.0 \pm 4.0(8)^{b}$ \\
\hline
\end{tabular}

a after activation with citrate

${ }^{b} \mathrm{p}<0.05$ compared with preobese animals in group A and lean animals in group B

Values represent the mean \pm SEM for the number of observations shown in parentheses

adipose tissue of all the pups. However, the accumulation of $\left[{ }^{3} \mathrm{H}\right]$-fatty acids was now significantly greater in the adipose tissue of the preobese pups than in the lean pups, but the levels of hepatic $\left[{ }^{3} \mathrm{H}\right]$-fatty acids were not statistically different between lean and preobese pups. The lipogenic rates presented in Table 1 are expressed on a whole tissue basis since the fat pads of preobese pups were considerably heavier than those of the lean pups, although the weights were not affected by the availability of chow diet. Liver weights were similar in all animals (data not shown). In streptozotocin-treated pups the accumulation of $\left[{ }^{3} \mathrm{H}\right]$-fatty acids in the liver of lean and preobese pups was similar but it was still enhanced in the adipose tissue of the preobese $f a / f a$ rats in comparison to their lean siblings. The weights of the fat pads of the streptozotocin-treated pups was surprisingly increased in comparison to the other groups of animals. This was probably a consequence of two factors: the relatively smaller litter size (mean 5.1 versus 9.4 pups of untreated litters) and the fact that these animals were not sacrificed until days 21-24 instead of day 20 for the other groups.

The activities of G6PDH, acetyl CoA carboxylase and fatty acid synthetase in the liver and adipose tissue of lean and preobese rats are shown in Table 2. No significant changes were observed in either the liver or the adipose tissue of preobese $f a / f a$ rats denied access to the high carbohydrate chow diet, despite their increase in adipose tissue mass. In those litters given access to solid food, fatty acid synthetase, acetyl CoA carboxylase and G6PDH activities were all increased in the adipose tissue of preobese $f a / f a$ rats but were unchanged in the liver.

The effect of pretreatment with Triton WR 1339 on the accumulation of $\left[{ }^{3} \mathrm{H}\right]$-fatty acids in adipose 
Table 3. The accumulation of $\left[{ }^{3} \mathrm{H}\right]$-fatty acid in the liver and adipose tissue of 18-21 day old preobese $f a / f a$ rats after injection with Triton WR 1339

\begin{tabular}{|c|c|c|c|}
\hline & \multirow{2}{*}{$\begin{array}{l}\text { Serum } \\
\text { triacylglycerol } \\
(\mathrm{mmol} / \mathrm{l})\end{array}$} & \multicolumn{2}{|l|}{$\begin{array}{l}\text { Fatty acid synthesis } \\
\text { ( } \mu \mathrm{mol} / \mathrm{h} \text { per organ) }\end{array}$} \\
\hline & & Liver & Fat pad \\
\hline Lean & $7.6 \pm 0.7(9)^{\mathrm{a}}$ & $0.98 \pm 0.10(11)$ & $0.35 \pm 0.06(10)$ \\
\hline Preobese & $\begin{array}{l}8.4 \pm 1.4(6) \\
\text { N.S. }\end{array}$ & $\begin{array}{l}1.40 \pm 0.24(8) \\
\text { N.S. }\end{array}$ & $\begin{array}{l}2.42 \pm 0.90(8) \\
p<0.02\end{array}$ \\
\hline
\end{tabular}

Values represent the mean \pm SEM for the number of observations shown in parentheses. Rats were given $0.1 \mathrm{ml} 20 \%$ (w/v) Triton WR 1339 in saline by intra-cardiac injection immediately before administration of ${ }^{3} \mathrm{H}_{2} \mathrm{O}$ for assay of fatty acid synthesis.

a Only those animals showing a major increase in serum triacylglycerol concentrations are included. Control values for serum triacylglycerol were $1.0 \pm 0.1 \mathrm{mmol} / \mathrm{l}$ for lean and $1.4 \pm 0.1 \mathrm{mmol} / 1$ for preobese.

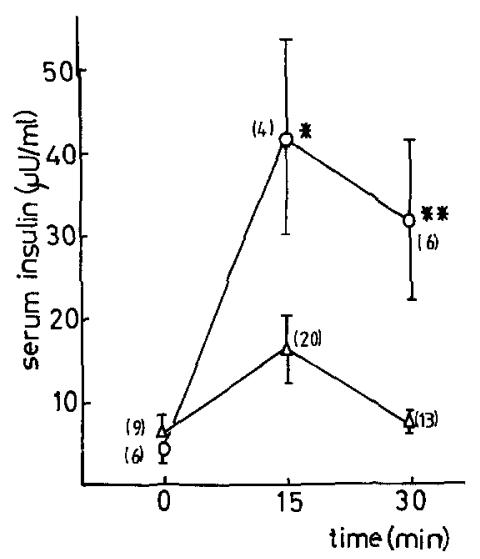

Fig. 1. Glucose-induced insulin secretion in suckling lean and preobese rats given access to a chow diet. The 20-day-old rat pups were separated from the mother at $08.30 \mathrm{~h}$. At $10.30 \mathrm{~h}$ they were either sacrificed or injected IP with $1 \mathrm{mg}$ glucose per g body weight and sacrificed after a further 15 or $30 \mathrm{~min}$. The values represent the mean $\pm S E M$ for the number of observations shown in parentheses.

$(\triangle \longrightarrow \triangle$ lean; $O \longrightarrow O$ preobese $) .{ }^{*} p<0.05 ; * * p<0.001 \mathrm{com}-$ pared with lean controls

tissue is shown in Table 3. Only those animals showing a significant rise in serum triacylglycerol levels were included in these results. After Triton WR 1339 serum triacylglycerols accumulated to a similar degree in both lean and preobese rats. Despite this, a sevenfold increase in the accumulation of $\left[{ }^{3} \mathrm{H}\right]$-fatty acids in adipose tissue was still observed in preobese fatty rats. The apparent level of fatty acid synthesis was similar to that previously observed in adipose tissue of preobese rats allowed access to chow diet (Table 1).
Although no differences were apparent in the serum insulin of lean and preobese rats given access to a chow diet, the secretory response of the B cells was investigated in response to a glucose load of $1 \mathrm{mg} / \mathrm{g}$ body weight, given by IP injection (Fig. 1). Serum insulin was significantly increased by $15 \mathrm{~min}$ but had returned to basal levels by $30 \mathrm{~min}$ in lean rats. In contrast, preobese fatty rats given access to chow diet showed an enhanced and prolonged insulin secretory response.

\section{Discussion}

The ability to recognise genetically inherited obesity in preobese animals either through their lower rectal temperatures $[2,17]$, lower oxygen consumption $[18$, $19]$ or by their coat colour $[10,12,20,21]$ has facilitated studies of the early metabolic changes in the preobese state. From studies on the $m d b / m d b$ mouse, it has been suggested that a small $(25 \%)$ increase in serum insulin levels $[12,21]$ may be responsible at least in part for the increase in lipoprotein lipase and fat deposition in the suckling animal $[10,21]$. The failure to observe any increase in fatty acid synthesis despite the small increase in serum insulin has been attributed to the suppression of lipogenesis by the high fat milk diet. Similarly, in the suckling preobese $f a / f a$ rats investigated in this study, there was no observable increase in either adipose tissue or hepatic lipogenesis or in their lipogenic enzyme activities. These results confirm and extend our earlier observations on hepatic lipogenesis and support the recent in vitro measurements of enzyme activities and of $\mathrm{U}-\left[{ }^{14} \mathrm{C}\right]$-glucose conversion into fatty acids in adipose tissue and liver by Smith and Kaplan [22]. Weaning from the high fat milk diet to the high carbohydrate rat diet is known to be the signal for large increases in insulin secretion and hepatic and adipose tissue lipogenesis in lean rodents and for excessive increases in preobese $o b / o b$ and $d b / d b$ mice and in $f a / f a$ rats $[1,2,10,21,22]$.

Although measurements of milk intake by suckling animals is difficult, the assessment of $\left[{ }^{3} \mathrm{H}\right]$ accumulation in the body water of pups after labelling of the maternal milk with ${ }^{3} \mathrm{H}_{2} \mathrm{O}$ has failed to show any differences in intake between lean and preobese animals [7, 23]. However, it has been suggested that preobese animals may be characterised by an early increase in the intake of solid food [7,23]. Close observation of suckling pups shows that they begin to eat small quantities of the maternal diet from about 14 days of age. The rise in serum insulin observed in both lean and preobese $f a / f a$ rats given access to the high carbohydrate diet would support 
these observations of solid food intake before weaning. Such serum insulin values could also be regarded as stimulated levels whereas those in the rats maintained on a strict suckling regime may be regarded as basal insulin levels. Despite these observations the preobese $f a / f a$ rat clearly showed an enhanced insulin secretion in response to an acute glucose stimulation suggesting that the increase in insulin secretory capacity is already present before weaning. Similarly, an increase in insulin secretion has been observed in preobese suckling mice $[10,20]$. The inability to detect any increase in serum insulin of the preobese $f a / f a$ rats given access to chow diet may result from individual variations in the time and quantity of chow eating. Thus, a small increase in insulin secretion may not be detectable by a single insulin measurement in each rat.

The reported studies suggest that lipogenesis in both the liver and adipose tissue of preobese $f a / f a$ rats was normal when the pups were restricted to maternal milk. However, when maternal rat chow was available, there was a disproportionate elevation in the accumulation of $\left[{ }^{3} \mathrm{H}\right]$-fatty acids in the adipose tissue of the preobese rats. The absence of any apparent increase in hepatic $\left[{ }^{3} \mathrm{H}\right]$-fatty acid levels with the increase in serum insulin could have resulted from an enhancement in the rate of transport of endogenously synthesised fatty acids from the liver to the adipose tissue in the form of VLDL. Such an increase in VLDL production and transport has been reported in the weaned and adult $f a / f a$ rat $[1,24,25]$. However, this interpretation seems unlikely in this case as the activities of G6PDH, acetyl CoA carboxylase and fatty acid synthetase were not increased in the liver of the preobese $f a / f a$ rats. It is further supported by the demonstration that serum triacylglycerols rose to similar levels in lean and preobese rats after inhibition of lipoprotein lipase with Triton WR 1339, suggesting that the rate of hepatic triacylglycerol production was similar in the two groups. The failure of Triton WR 1339 to prevent the excess accumulation of $\left[{ }^{3} \mathbf{H}\right]$-fatty acids in adipose tissue of preobese rats would also suggest that the adipose tissue per se is responsible for the extra synthesis of fatty acids.

No increases in lipogenic enzyme activities were observed in lean rats with access to chow despite their increase in serum insulin and enhanced lipogenesis, the explanation for which remains obscure. The increase in adipose tissue fatty acid synthesis and in lipogenic enzyme activities in the preobese rat with access to chow could be a result of small intermittent increases in insulin secretion during chow feeding that were not detected in serum samples taken at a single time point. Such an increase in insulin secretion is however unlikely to explain the rise in adipose tissue lipoprotein lipase activity that has been observed as early as day $7[7,26]$ in the fatty rat since at this age animals are entirely dependent upon their high fat maternal milk supply. The lack of any significant change in hepatic lipogenesis in the preobese or lean $f a / f a$ rats despite wide variations in serum insulin induced either by chow availability or streptozotocin treatment suggests that hepatic fatty acid synthesis is insensitive to insulin regulation during this stage of development when the diet consists entirely or mainly of the high fat maternal milk. In contrast the rate of adipose tissue fatty acid synthesis varied with the changing serum insulin levels although the differences between lean and preobese rats remained. These results suggest that adipose tissue fatty acid synthesis is responsive to increasing insulin levels in the suckling rat. It is possible that the increase in adipose tissue lipogenesis in the preobese $f a / f a$ rat given access to chow could be secondary to a hypersecretion of insulin although no detectable increase was found in serum insulin in chow fed preobese rats under basal conditions.

At 20 days of age the weight of the subcutaneous fat pad on the hind limb of preobese $f a / f a$ rats was approximately twice that of their lean littermates. These results are in agreement with many other observations on the development of obesity in the $f a / f a$ rat and the mouse recessively inherited obesities $[3,7-11,13,21,26]$. However, from the results reported in this study it would appear that this difference in fat deposition was independent of the availability of high carbohydrate diet and increased lipogenesis before weaning although the lipogenic rates observed were still very small in comparison to those observed after weaning $[1,2]$. The precise relationship of the early increase in lipoprotein lipase and fat deposition to the increase in insulin secretory capacity awaits further experimentation.

Acknowledgements. This work was supported by a project grant from the Medical Research Council.

\section{References}

1. Godbole V, York DA (1978) Lipogenesis in situ in the genetically obese Zucker rat $(f a / f a)$. Role of hyperphagia and hyperinsulinaemia. Diabetologia 14: 191-197

2. Godbole V, York DA, Bloxham D (1978) Developmental changes in the fatty $(f a / f a)$ rat: Evidence for defective thermogenesis preceding the hyperlipogenesis and hyperinsulinaemia. Diabetologia 15: 41-44

3. Zucker LM, Antoniades H (1972) Insulin and obesity in the Zucker genetically obese rat 'fatty'. Endocrinology 90: $1320-1330$

4. Martin RJ (1974) In vivo lipogenesis and enzyme levels in adipose tissue and liver from pair-fed genetically obese and lean rats. Life Sci 14: 1447-1453 
5. Martin RJ, Lamprey PM (1975) Early development of adipose cell lipogenesis and glycerol utilisation in Zucker obese rats. Proc Soc Exp Biol Med 149: 35-39

6. Martin RJ, Gahagan J (1977) Serum hormone levels and tissue metabolism in pair-fed lean and obese Zucker rats. Horm Metab Res 9: 181-186

7. Boulange A, Planche E, de Gasquet P (1979) Onset of genetic obesity in the absence of hyperphagia during the first week of life in the Zucker rat (fa/fa). J Lipid Res 20: 857-864

8. Bell GE, Stern JS (1977) Evaluation of body composition of young obese and lean Zucker rats. Growth 41: 63-80

9. Gruen R, Hiethnen E, Greenwood MRC (1978) Increased adipose tissue lipoprotein lipase activity during the development of the genetically obese rat $(f a / f a)$. Metabolism 27: 1955-1966

10. Jeanrenaud B (1978) An overview of experimental models of obesity. In: Bray GA (ed) Recent advances in obesity research, vol 2. Newman Publishing Co, London, pp 111-122

11. Bray GA, York DA (1979) Hypothalamic and genetic obesity in experimental animals: an autonomic and endocrine hypothesis. Physiol Rev 59: 719-809

12. Coleman DL, Hummel KP (1976) Hyperinsulinaemia in preweaning diabetes $(\mathrm{db})$ mice. Diabetologia $10 ; 607-610$

13. Dubuc P (1976) The development of obesity, hyperinsulinaemia and hyperglycemia in $a b / o b$ mice. Metabolism 25: 1567-1574

14. Inoue H, Lowenstein JM (1975) Acetyl Coenzyme A carboxylase from rat liver. In: Lowenstein JM (ed) Methods in enzymology, vol 35. Academic Press, London, pp 3-11

15. Nepokroeff CM, Lakshmanan MR, Porter JW (1975) Fatty acid synthetase from rat liver. In: Lowenstein JM (ed) Methods in enzymology, vol 35. Academic Press, London, pp 37-44

16. Rush RL, Leon L, Turrell J (1970) Automated simultaneous cholesterol and triglyceride determination in the autoanalyser II instrument. Adv Autom Anal I: 503-507

17. Trayhurn P, James WPT (1978) Thermoregulation and nonshivering thermogenesis in the genetically obese (ob/ob) mouse. Pflugers Arch 373: 189-193
18. Kaplan ML (1979) Consumption of $\mathrm{O}_{2}$ and early detection of fa/fa genotype in rats. Metabolism 28: 1147-1151

19. Kaplan ML, Leveille GA (1974) Core temperature, oxygen consumption and early detection of ob/ob genotype in mice. Am J Physiol 227: 912-915

20. Coleman DL (1978) Obesity and diabetes. Two mutant genes causing obesity-diabetes syndromes in mice. Diabetologia 14 : 141-148

21. Le Marchand-Brustel Y, Jeanrenaud B (1978) Pre- and postweaning studies on the development of obesity in the $\mathrm{mdb}$ / mdb mice. Am J Physiol 234: E568-E574

22. Smith PA, Kaplan ML (1980) Development of hepatic and adipose tissue lipogenesis in the fa/fa rat. Int J Biochem 11: 217-228

23. Rath EA, Thenen SW (1979) Use of tritiated water for measurement of 24 hour milk intake in suckling lean and genetically obese $(o b / o b)$ mice. J Nutr 109: 840-847

24. Schonfeld G, Pfleger B (1971) Overproduction of very low density lipoprotein by livers of genetically obese rats. Am J Physiol 226: 1178-1184

25. Schonfeld G, Felski C, Howald M (1974) Characterisation of the plasma lipoproteins of the genetically obese hyperlipoproteinaemic Zucker fatty rat. J Lipid Res 15: 457-464

26. Greenwood MRC, Gruen R, Cleary MP (1978) Adipose tissue growth and the development of fat cells. In: Bray GA (ed) Recent advances in obesity research, vol 2. Newman Publishing Ltd, London, pp 169-182

Received: 22 July 1980

received in revised form: 13 February 1981

Dr. D. A. York

Department of Nutrition

School of Biochemical and Physiological Sciences

University of Southampton

Southampton S09 5NH, UK 